\title{
Pengaruh Model Tumpangsari dan Pengaturan Jarak Tanam Kacang Nasi (Vigna angularis L.) Kultivar Lokal terhadap Pertumbuhan dan Hasil Tanaman Jagung (Zea mays L.)
}

Fransiskus Xaverius $\mathrm{Neo}^{\mathrm{a}}$, dan Syprianus Ceunfin ${ }^{\mathrm{b}}$

${ }^{a}$ Fakultas Pertanian, Universitas Timor, Kefamenanu, TTU - NTT, Indonesia.

${ }^{b}$ Fakultas Pertanian, Universitas Timor, Kefamenanu, TTU - NTT, Indonesia.

\section{Article Info}

Article history:

Received 6 Juni 2017

Received in revised form 26 Maret 2017

Accepted 27 Maret 2018

\section{Keywords:}

Model Tumpangsari

Pengaturan Jarak Tanam

Zea mays L.

Vigna angularis $\mathrm{L}$

\section{Abstrak}

Tanaman jagung dan kacang nasi adalah dua jenis tanaman yang cocok diterapkan pada pola tumpangsari. Penelitian ini bertuju an untuk mengetahui 1) pertumbuhan dan hasil jagung dalam pola tanam tumpangsari; 2) model tumpangsari terbaik dalam meningkatkan pertumbuhan dan hasil jagung; dan 3) pengaturan jarak tanam yang baik dalam pola tanam tumpangsari jagung dan kacang nasi. Penelitian dilaksanakan di kebun percobaan Fakultas Pertanian Universitas Timor, pada bulan Desember 2016 sampai Maret 2017, menggunakan Rancangan Acak Kelompok (RAK) faktorial yang diulang tiga kali. Faktor pertama adalah model tumpangsari yang terdiri dari tiga aras yaitu tumpangsari standar nasional (sistem sela), tumpangsari Salome (model timor) dan gabungan. Faktor kedua adalah pengaturan Jarak tanam yang terdiri dari dua aras yaitu single row dan doble row. Hasil penelitian menunjukkan interaksi antara model tumpangsari dan pengaturan jarak tanam terhadap parameter pengamatan berat kering biji per petak, berat kering biji per hektar. Tanaman jagung yang ditumpangsarikan dengan kacang nasi pada perlakuan model tumpangsari Salome dengan pengaturan jarak tanam doble row menghasilkan berat kering biji per petak paling tinggi yaitu sebesar $269,31 \mathrm{~g}$ dan 0,89 t/ha. (O2018 dipublikasikan oleh Savana Cendana.

\section{Pendahuluan}

Jagung (Zea mays L.) merupakan komoditas yang sangat penting selain padi terutama di negara Indonesia. Jagung merupakan bahan pangan yang berperan penting dalam perekonomian, mudah diterima masyarakat, karena merupakan pangan tradisional. Jagung mempunyai peranan penting dalam hal penyediaan bahan pangan, bahan baku industri dan pakan ternak. Jagung memiliki kandungan gizi seperti karbohidrat, protein dan lemak (Agustina, 2008). Kandungan gizi jagung tidak kalah dengan beras atau terigu, bahkan jagung memiliki keunggulan karena merupakan pangan fungsional dengan kandungan serat pangan, unsur Fe dan beta-karoten (pro vitamin A) yang tinggi (Suarni, 2001).

Jagung lokal merupakan varietas lokal yang masih dikembangkan oleh petani di beberapa wilayah Indonesia, yang sebenarnya merupakan sumber jagung yang dapat menghasilkan benih atau bibit unggul apabila telah melalui proses pemuliaan. Data BPS NTT (2014), pada periode 2010-2011 luas panen jagung meningkat dari 244.600 ha menjadi 246.900 ha tetapi produksinya menurun dari $653.600 \mathrm{t}$ menjadi $524.600 \mathrm{t}$ atau turun sebesar $19,74 \%$. Kondisi ini disebabkan menurunnya produktifitas jagung dari $25,50 \mathrm{kw} / \mathrm{ha}$ pada tahun 2009 menjadi $21,25 \mathrm{kw} / \mathrm{ha}$ pada tahun 2011 atau mengalami penurunan produktivitas rata-rata sebesar $8,34 \%$ per tahun. Maka dari itu dalam rangka mewujudkan Nusa Tenggara Timur (NTT) sebagai Provinsi jagung selain perluasan areal tanaman juga perlu perhatian serius terhadap upaya peningkatan produktivitas jagung. Hingga tahun 2014 luas panen telah mencapai 270.396 ha produktivitas meningkat hingga $26,17 \mathrm{kw} / \mathrm{ha}$ dan produksi mencapai $707.643 \mathrm{t}$ Produksi tanaman jagung di Kabupaten TTU periode tahun 2008 hingga 2011 mengalami fluktuasi. Produksi jagung tahun 2008 hingga 2011 berturut-turut sebesar 31.427 t, 55.498 t, 54.027 dan 35.048 (BPS TTU, 2012).

Kacang nasi (Vigna angularis L.) dalam bahasa daerah di kabupaten Timor Tengah Utara (TTU) disebut fuemtas'ana atau fuesilu, merupakan tanaman palawija berpolong yang telah lama dikenal oleh masyarakat sebagai bahan makanan bergizi yang biasanya dimasak bersama nasi. Di Indonesia tanaman kacang nasi biasanya ditanam di pematang sawah atau sebagai tanaman selingan di antara tanaman jagung dengan tanaman palawija lainnya. Pada akar tanaman kacang nasi terdapat bintil-bintil akar yang dapat berfungsi menyerap unsur nitrogen bebas dari udara sehingga dapat menyuburkan tanah. Di Kabupaten TTU, kacang nasi dibudidayakan secara tumpangsari dengan tanaman jagung. Kacang nasi ini merupakan tanaman semusim (annual) yang bersifat merambat dan memiliki daya adaptasi yang cukup luas terhadap lingkungan tumbuh. Menurut Irfan (1999), selain memiliki daya adaptasi yang tinggi, kacang nasi memiliki akar yang berbentuk panjang dan memiliki bintil-bintil (nodula) yang merupakan sumber unsur nitrogen.

Tumpangsari (intercropping) merupakan suatu usaha menanam beberapa jenis tanaman pada lahan dan waktu yang sama (Setiawan, 2009). Misalnya jagung, kacang-kacangan dan ubi-ubian. Menurut Warsawa (2009), beberapa keuntungan pada pola tumpangsari antara lain: 1) akan terjadi peningkatan efisiensi (tenaga kerja, pemanfaatan lahan maupun penyerapan sinar matahari), 2) populasi tanaman dapat diatur sesuai yang dikehendaki, 3) dalam satu areal diperoleh produksi lebih dari satu komoditas, 4) tetap mempunyai peluang mendapatkan hasil manakala satu jenis tanaman yang diusahakan gagal dan 5) kombinasi beberapa jenis tanaman dapat menciptakan beberapa jenis tanaman dapat menciptakan stabilitas biologis sehingga dapat menekan serangan hama dan penyakit serta mempertahankan kelestarian sumber daya lahan dalam hal ini kesuburan tanah.

Rendahnya produktivitas jagung disebabkan karena kondisi iklim, tingkat kesuburan tanah yang rendah, dan teknik budidaya yang masih sederhana, seperti pengaturan jarak tanam yang belum optimal. Permasalahannya masyarakat belum memahami pola tanam yang teratur. Maka perlu teknologi lain untuk mencapai hasil yang optimum, seperti pengaturan jarak tanam.

Jarak tanam yang tepat maka populasi tanaman per satuan luas lahan maksimum dan persaingan antara tanaman dalam penyerapan air, unsur hara maupun cahaya matahari sebagai sumber energi utama tidak pada tingka merugikan. Pengaturan jarak tanam pada suatu areal tanah pertanian merupakan salah satu cara yang berpengaruh terhadap hasil yang akan dicapai. Makin rapat jarak tanam menyebabkan lebih banyak tanaman yang tidak berbuah. Harjadi (2002) menyatakan bahwa jarak tanam juga mempengaruhi persaingan antar tanaman dalam mendapatkan air dan unsur hara, sehingga akan mempengaruhi hasil (Setyamidjaja, 2000).

Kerapatan tanaman merupakan faktor yang mempengaruhi pertumbuhan tanaman, karena penyerapan energi matahari oleh permukaan daun. Jika kondis tanaman terlalu rapat dapat mempengaruhi perkembangan vegetatif dan hasil panen akibat menurunnya laju fotosintesa dan menurunnya perkembangan luas daun, oleh karena itu dibutuhkan jarak tanam yang optimum untuk memperoleh hasil yang maksimum (Mayadewi, 2007). Penelitian ini bertujuan untuk mengetahui pengaruh model tumpangsari dan pengaturan jarak tanam kacang nasi terhadap pertumbuhan dan hasil jagung lokal.

\section{Metode}

Penelitian dilaksanakan bulan Desember 2016 sampai Maret 2017 lahan Universitas Timor, Kelurahan Sasi, kecamatan Kota Kefamenanu, Kabupaten TTU, Provinsi NTT, dengan menggunakan Rancangan Acak Kelompok (RAK) faktorial. Faktor pertama adalah model tumpangsari yang terdiri dari tiga aras yaitu tumpangsari standar nasional (sistem sela $=S_{1}$ ), tumpangsari Salome (model Timor $=S_{2}$ ) dan gabungan $\left(S_{2}+S_{1}=S_{3}\right)$. Faktor kedua adalah pengaturan jarak tanam dengan dua aras yakni single row $\left(\mathrm{J}_{1}\right)$ dan double row. Kombinasi perlakuannya adalah $S_{1} J_{1}, S_{1} J_{2}, S_{2} J_{1}, S_{2} J_{2}, S_{3} J_{1}, S_{3} J_{2}+3$ (kontrol) yang diulang 3 kali. Lahan dibersihkan dari gulma serta vegetasi lainnya untuk kemudian dilanjutkan dengan pengolahan. Pengolahan tanah dilakukan dengan menggunakan cangkul, kemudian tanah digemburkan. Lahan yang digunakan berukuran panjang $7 \mathrm{~m}$, lebar $6,40 \mathrm{~m}$ dengan luas lahan $44,8 \mathrm{~m}^{2}$. Lahan dibag dalam tiga blok dalam satu blok terdapat 9 petak percobaan dengan ukuran petak $2,5 \mathrm{~m} \times 1,2 \mathrm{~m}$. Sebelum penanaman, dilakukan sortasi terhadap benih jagung dan kacang. Penanaman dilakukan dengan cara tugal sedalam $\pm 3 \mathrm{~cm}-5 \mathrm{~cm}$. Jarak tanam yang digunakan adalah jarak tanam standar, $70 \times 20 \mathrm{~cm}$ untuk tanaman jagung, $35 \times 20 \mathrm{~cm}$ untuk tanaman kacang nasi. Jumlah benih setiap lubang tanam adalah 3 benih per lubang tanam kemudian menyisakan 2 tanaman setelah benih tumbuh dan berumur 14 hari untuk tanaman jagung maupun tanaman kacang nasi. Pupuk yang digunakan adalah Guano dengan takaran 8,5 t/ha dan kompos 15 t/ha yang setara.

Parameter yang diamati yakni suhu tanah, kadar lengas tanah, tingg tanaman, diameter batang, jumlah daun, diameter tongkol, panjang tongkol, jumlah biji per baris, jumlah baris per tongkol, berat kering biji per tongkol, berat kering biji per petak, berat kering biji per hektar, berat kering 100 biji, berat kering berangkasan, indeks panen, kejadian penyakit bulai, dan Land Equivalent Ratio (LER) dengan menggunakan rumus menurut Beets (1982).

Semua data yang diperoleh ditabulasikan kemudian dianalisa dengan menggunakan sidik ragam (Anova) Rancangan Acak Kelompok (RAK), selanjutnya untuk mengetahui pengaruh perlakuan yang diberikan, rata-rata perlakuan diuji lanjut menggunakan Duncan Multiple Range Test (DMRT) pada a $5 \%$ sesuai petunjuk (Gomez \& Gomez, 1984). Analisis data menggunakan perangkat lunak (software) SAS for Windows 9.1

\section{Hasil dan Pembahasan \\ 3.1 Suhu Tanah}

Hasil sidik ragam (Anova) menunjukkan tidak terjadi interaksi antara model tumpangsari dan pengaturan jarak tanam terhadap suhu tanah. Selama penelitian, suhu tanah berkisar antara $27^{\circ} \mathrm{C}-34^{\circ} \mathrm{C}$, dimana suhu tanah di awal pengamatan meningkat dan cendrung menurun di akhir pengamatan. Penurunan suhu tanah tersebut diakibatkan oleh penutupan permukaan tanah oleh tajuk tanaman. 
Tabel 1. Suhu Tanah $\left({ }^{\circ} \mathrm{C}\right)$

\begin{tabular}{cllll}
\hline Hari & \multicolumn{1}{c}{ Model } & \multicolumn{2}{c}{ Pengaturan Jarak Tanam } & \multirow{2}{*}{ Rerata } \\
\cline { 3 - 4 } Pengamatan & Tumpang Sari & Single Row & Doble Row & \\
\hline \multirow{5}{*}{ 14 HST } & Kontrol & 34,18 & 34,88 & $34,52 \mathrm{a}$ \\
& Standar nasional & 34,00 & 34,66 & $34,32 \mathrm{a}$ \\
& Salome & 34,92 & 33,87 & $34,39 \mathrm{a}$ \\
& Gabungan SN-S & 35,36 & 34,40 & $34,87 \mathrm{a}$ \\
\cline { 2 - 4 } & Rerata & $34,61 \mathrm{a}$ & $34,45 \mathrm{a}$ & $(-)$ \\
\hline \multirow{5}{*}{28 HST } & Kontrol & 30,81 & 29,73 & $30,27 \mathrm{a}$ \\
& Standar nasional & 30,06 & 30,52 & $30,28 \mathrm{a}$ \\
& Salome & 30,51 & 30,44 & $30,47 \mathrm{a}$ \\
& Gabungan SN-S & 30,26 & 31,37 & $30,81 \mathrm{a}$ \\
\hline \multirow{5}{*}{$42 \mathrm{HST}$} & Rerata & $30,41 \mathrm{a}$ & $30,52 \mathrm{a}$ & $(-)$ \\
\hline & Kontrol & 27,06 & 27,02 & $27,03 \mathrm{a}$ \\
& Standar nasional & 26,49 & 27,01 & $26,75 \mathrm{a}$ \\
& Salome & 27,58 & 27,17 & $27,37 \mathrm{a}$ \\
& Gabungan SN-S & 27,09 & 27,27 & $27,17 \mathrm{a}$ \\
\cline { 2 - 4 } & Rerata & $27,05 \mathrm{a}$ & $27,12 \mathrm{a}$ & $(-)$ \\
\hline
\end{tabular}

Keterangan : Angka pada baris dan kolom yang diikuti dengan huruf yang sama menunjukkan tidak berbeda pada tingkat nyata $(\alpha) 5 \%$ menurut uji DMRT; (-): Tidak terjadi interaksi antar faktor.

\subsection{Kadar Lengas Tanah}

Hasil sidik ragam (Anova) menunjukkan tidak terjadi interaksi antara model tumpangsari dan pengaturan jarak tanam terhadap pengamatan kadar lengas tanah. Rata-rata kadar lengas tanah untuk perlakuan model tumpangsari yang tertinggi terdapat pada kontrol $(29,11)$ dibanding standar nasional, salome dan gabungan. Demikian pula untuk pengaturan jarak tanam, rata-rata kadar lengas tertinggi adalah doble row $(28,24)$ dibanding single row.

Tabel 2. Kadar Lengas Tanah (\%)

\begin{tabular}{lllc}
\hline \multirow{2}{*}{ Model Tumpang } & \multicolumn{2}{c}{ Pengaturan Jarak Tanam } & \multirow{2}{*}{ Rerata } \\
\cline { 2 - 3 } & Single Row & Doble Row & \\
\hline Kontrol & 27,66 & 26,86 & $29,11 \mathrm{a}$ \\
Standar nasional & 31,02 & 27,20 & $28,39 \mathrm{a}$ \\
Salome & 23,46 & 33,33 & $27,58 \mathrm{a}$ \\
Gabungan SN-S & 29,60 & 25,56 & $27,26 \mathrm{a}$ \\
\hline Rerata & 27,93 a & $28,24 \mathrm{a}$ & $(-)$
\end{tabular}

Keterangan : Angka pada baris dan kolom yang diikuti dengan huruf yang sama menunjukkan tidak berbeda pada tingkat nyata $(\alpha) 5 \%$ menurut uji DMRT; (-): Tidak terjadi interaksi antar faktor.

\subsection{Tinggi Tanaman}

Hasil sidik ragam (Anova) menunjukkan tidak terjadi interaksi antara model tumpangsari dan pengaturan jarak tanam terhadap pengamatan tinggi tanaman. Pengamatan 14 HST untuk model tumpang sari terdapat beda nyata, dimana gabungan memiliki tinggi tanaman tertinggi $(39,50)$ dibanding standar nasional, salome dan kontrol, sedangkan pengamatan ke 28-42 HST tidak terdapat beda nyata namun tanaman cendrung meningkat dibanding kontrol. Demikian pula pengaturan jarak tanam dobel row cendrung meningkat pada tiap pengamatan dibanding single row.

Tabel 3. Tinggi Tanaman $(\mathrm{cm})$

\begin{tabular}{|c|c|c|c|c|}
\hline \multirow{2}{*}{$\begin{array}{c}\text { Waktu } \\
\text { Pengamatan }\end{array}$} & \multirow{2}{*}{$\begin{array}{l}\text { Model } \\
\text { Tumpang Sari }\end{array}$} & \multicolumn{2}{|c|}{ Pengaturan Jarak Tanam } & \multirow{2}{*}{ Rerata } \\
\hline & & Single Row & Doble Row & \\
\hline \multirow{5}{*}{14 HST } & Kontrol & 35,67 & 29,22 & $32,44 \mathrm{~b}$ \\
\hline & Standar nasional & 35,06 & 34,61 & $34,83 \mathrm{ab}$ \\
\hline & Salome & 34,89 & 40,83 & $37,86 a b$ \\
\hline & Gabungan SN-S & 40,67 & 38,33 & $39,50 \mathrm{a}$ \\
\hline & Rerata & $36,57 \mathrm{a}$ & $35,75 \mathrm{a}$ & $(-)$ \\
\hline \multirow{5}{*}{$28 \mathrm{HST}$} & Kontrol & 47,11 & 44,56 & $45,83 \mathrm{a}$ \\
\hline & Standar nasional & 49,28 & 51,78 & $50,52 \mathrm{a}$ \\
\hline & Salome & 49,50 & 55,56 & $52,53 \mathrm{a}$ \\
\hline & Gabungan SN-S & 53,06 & 52,11 & $52,58 \mathrm{a}$ \\
\hline & Rerata & $49,74 \mathrm{a}$ & $51,00 \mathrm{a}$ & $(-)$ \\
\hline \multirow{5}{*}{$42 \mathrm{HST}$} & S0 (Kontrol) & 65,83 & 63,56 & 64,69 a \\
\hline & Standar nasional & 72,17 & 77,17 & 74,66 a \\
\hline & Salome & 64,00 & 91,67 & $77,83 \mathrm{a}$ \\
\hline & Gabungan SN-S & 80,72 & 66,50 & $73,61 \mathrm{a}$ \\
\hline & Rerata & $70,68 \mathrm{a}$ & $74,72 \mathrm{a}$ & $(-)$ \\
\hline
\end{tabular}

Keterangan : Angka pada baris dan kolom yang diikuti dengan huruf yang sama menunjukkan tidak berbeda pada tingkat nyata $(\alpha) 5 \%$ menurut uj DMRT; (-): Tidak terjadi interaksi antar faktor.

\subsection{Diameter Batang}

Hasil sidik ragam (Anova) menunjukkan tidak terjadi interaksi antara model tumpangsari dan pengaturan jarak tanam terhadap pengamatan diameter batang. Selama penelitian, diameter batang berkisar antara $0,48-1,87$, dimana diameter batang di awal pengamatan menurun dan cendrung meningkat di akhir pengamatan. Hasil uji lanjut menunjukkan bahwa pengamatan 14 HST dan 28 HST tidak terjadi perbedaan secara nyata, tetapi pengaturan jarak tanam diameter lebih besar pada pengamatan 28 HST, pada pengamatan pengaturan jarak tanam single row memiliki diameter lebih besar pada pengamatan 42 HST dibanding tumpangsari lainnya.

Tabel 4. Diameter Batang $(\mathrm{cm})$

\begin{tabular}{|c|c|c|c|c|}
\hline \multirow{2}{*}{$\begin{array}{c}\text { Waktu } \\
\text { Pengamatan }\end{array}$} & \multirow{2}{*}{$\begin{array}{l}\text { Model } \\
\text { Tumpang Sari }\end{array}$} & \multicolumn{2}{|c|}{ Pengaturan Jarak Tanam } & \multirow{2}{*}{ Rerata } \\
\hline & & Single Row & Doble Row & \\
\hline \multirow{5}{*}{$14 \mathrm{HST}$} & Kontrol & 0,56 & 0,48 & $0,51 \mathrm{a}$ \\
\hline & Standar nasional & 0,48 & 0,60 & $0,54 \mathrm{a}$ \\
\hline & Salome & 0,48 & 0,62 & $0,55 \mathrm{a}$ \\
\hline & Gabungan SN-S & 0,56 & 0,54 & $0,54 \mathrm{a}$ \\
\hline & Rerata & $0,52 \mathrm{a}$ & $0,56 \mathrm{a}$ & $(-)$ \\
\hline \multirow{5}{*}{$28 \mathrm{HST}$} & Kontrol & 1,23 & 1,11 & $1,17 \mathrm{a}$ \\
\hline & Standar nasional & 1,28 & 1,47 & $1,37 \mathrm{a}$ \\
\hline & Salome & 1,24 & 1,50 & $1,37 \mathrm{a}$ \\
\hline & Gabungan SN-S & 1,49 & 1,07 & $1,28 \mathrm{a}$ \\
\hline & Rerata & $1,31 \mathrm{a}$ & $1,29 \mathrm{a}$ & $(-)$ \\
\hline \multirow{5}{*}{$42 \mathrm{HST}$} & Kontrol & 1,73 & 1,76 & $1,77 \mathrm{a}$ \\
\hline & Standar nasional & 1,62 & 1,77 & $1,69 \mathrm{a}$ \\
\hline & Salome & 1,87 & 1,68 & $1,74 \mathrm{a}$ \\
\hline & Gabungan SN-S & 1,81 & 1,64 & $1,72 \mathrm{a}$ \\
\hline & Rerata & $1,76 \mathrm{a}$ & $1,71 \mathrm{a}$ & $(-)$ \\
\hline
\end{tabular}

Keterangan : Angka pada baris dan kolom yang diikuti dengan huruf yang sama menunjukkan tidak berbeda pada tingkat nyata $(\alpha) 5 \%$ menurut uji DMRT; (-): Tidak terjadi interaksi antar faktor.

\subsection{Jumlah Daun}

Hasil sidik ragam (Anova) menunjukkan tidak terjadi interaksi antara model tumpangsari dan pengaturan jarak tanam terhadap jumlah daun. Rata-rata jumlah daun untuk pengamatan 42 (HST) model tumpangsari yang tertinggi terdapat pada standar nasional S1 $(9,25)$ dibanding gabungan salome dan kontrol. Demikian pula untuk pengaturan jarak tanam, rata-rata jumlah daun tertingg adalah doble row $(9,13)$ dibanding single row.

\section{Tabel 5. Jumlah Daun}

\begin{tabular}{|c|c|c|c|c|}
\hline \multirow{2}{*}{$\begin{array}{c}\text { Waktu } \\
\text { Pengamatan }\end{array}$} & \multirow{2}{*}{$\begin{array}{l}\text { Model } \\
\text { Tumpang Sari }\end{array}$} & \multicolumn{2}{|c|}{ Pengaturan Jarak Tanam } & \multirow{2}{*}{ Rerata } \\
\hline & & Single Row & Doble Row & \\
\hline \multirow{5}{*}{14 HST } & S0 (Kontrol) & 4,67 & 4,33 & $4,50 \mathrm{a}$ \\
\hline & Standar nasional & 4,72 & 4,61 & $4,66 \mathrm{a}$ \\
\hline & Salome & 4,50 & 4,61 & $4,55 \mathrm{a}$ \\
\hline & Gabungan SN-S & 5,00 & 4,44 & $4,72 \mathrm{a}$ \\
\hline & Rerata & $4,72 \mathrm{a}$ & $4,50 \mathrm{a}$ & $(-)$ \\
\hline \multirow{5}{*}{$28 \mathrm{HST}$} & Kontrol & 7,44 & 6,61 & $7,02 \mathrm{a}$ \\
\hline & Standar nasional & 7,28 & 7,61 & $7,44 \mathrm{a}$ \\
\hline & Salome & 6,83 & 8,00 & $7,41 \mathrm{a}$ \\
\hline & Gabungan SN-S & 7,67 & 6,50 & $7,08 \mathrm{a}$ \\
\hline & Rerata & $7,31 \mathrm{a}$ & $7,18 \mathrm{a}$ & $(-)$ \\
\hline \multirow{5}{*}{$42 \mathrm{HST}$} & Kontrol & 9,00 & 8,72 & $8,86 \mathrm{a}$ \\
\hline & Standar nasional & 9,22 & 9,28 & $9,25 \mathrm{a}$ \\
\hline & Salome & 8,22 & 9,33 & $8,77 \mathrm{a}$ \\
\hline & Gabungan SN-S & 8,94 & 9,17 & $9,05 \mathrm{a}$ \\
\hline & Rerata & $8,85 \mathrm{a}$ & $9,13 \mathrm{a}$ & $(-)$ \\
\hline
\end{tabular}

Keterangan : Angka pada baris dan kolom yang diikuti dengan huruf yang sama menunjukkan tidak berbeda pada tingkat nyata $(\alpha) 5 \%$ menurut uji DMRT; (-): Tidak terjadi interaksi antar faktor.

\subsection{Diameter Tongkol}

Hasil sidik ragam (Anova) menunjukkan tidak terjadi interaksi antara model tumpangsari dan pengaturan jarak tanam terhadap pengamatan diameter tongkol. Dimana tanpa ditumpangsarikan memiliki diameter tongkol tertinggi $(3,12)$ dibanding standar nasional, salome dan gabungan, tidak terdapat beda sangat nyata namun diameter tongkoll paling besar terdapat pada kontrol. Demikian pula pengaturan jarak tanam dobel row cendrung meningkat $(2,98)$ pada pengamatan dibanding single row.

Tabel 6. Diameter Tongkol $(\mathrm{cm})$

\begin{tabular}{llll}
\hline \multirow{2}{*}{ Model Tumpang Sari } & \multicolumn{2}{l}{ Pengaturan Jarak Tanam } & \multirow{2}{*}{ Rerata } \\
\cline { 2 - 3 } & Single Row & Doble Row & \\
\hline Kontrol & 2,91 & 3,33 & $3,12 \mathrm{a}$ \\
Standar nasional & 2,86 & 3,07 & $2,96 \mathrm{ab}$ \\
Salome & 2,64 & 2,99 & $2,81 \mathrm{ab}$ \\
Gabungan SN-S & 2,81 & 2,53 & $2,67 \mathrm{~b}$ \\
\hline Rerata & $2,80 \mathrm{a}$ & $2,98 \mathrm{a}$ & $(-)$ \\
\hline
\end{tabular}

Keterangan : Angka pada baris dan kolom yang diikuti dengan huruf yang sama menunjukkan tidak berbeda pada tingkat nyata $(\alpha) 5 \%$ menurut uji DMRT; (-): Tidak terjadi interaksi antar faktor.

\subsection{Panjang Tongkol}

Hasil sidik ragam (Anova) menunjukkan tidak terjadi interaksi antara model tumpangsari dan pengaturan jarak tanam terhadap pengamatan panjang tongkol. Dimana tanpa ditumpangsarikan memiliki panjang tingkol tertinggi $(7,93)$ 
dibanding standar nasional, salome dan gabungan, tidak terdapat beda sangat nyata namun panjang tongkol paling terpanjang terdapat pada kontrol. Demikian pula pengaturan jarak tanam doble row cendrung meningkat $(7,60)$ pada pengamatan dibanding single row.

Tabel 7. Panjang Tongkol (cm)

\begin{tabular}{|c|c|c|c|}
\hline \multirow{2}{*}{ Model Tumpang Sari } & \multicolumn{2}{|c|}{ Pengaturan Jarak Tanam } & \multirow{2}{*}{ Rerata } \\
\hline & Single Row & Doble Row & \\
\hline Kontrol & 6,55 & 9,30 & $7,93 \mathrm{a}$ \\
\hline Standar nasional & 7,44 & 7,61 & $7,52 \mathrm{a}$ \\
\hline Salome & 5,47 & 7,54 & $6,69 \mathrm{a}$ \\
\hline Gabungan SN-S & 7,42 & 5,97 & $6,50 \mathrm{a}$ \\
\hline Rerata & $6,72 \mathrm{a}$ & $7,60 \mathrm{a}$ & $(-)$ \\
\hline
\end{tabular}

Keterangan : Angka pada baris dan kolom yang diikuti dengan huruf yang sama menunjukkan tidak berbeda pada tingkat nyata $(\alpha) 5 \%$ menurut uji DMRT; (-): Tidak terjadi interaksi antar faktor.

\subsection{Jumlah Biji Per Baris}

Hasil sidik ragam (Anova) menunjukkan tidak terjadi interaksi antara model tumpangsari dan pengaturan jarak tanam terhadap pengamatan jumlah biji perbaris. Dimana tanpa ditumpangsarikan memiliki jumlah biji perbaris tertinggi $(12,48)$ dibanding standar nasional, salome dan gabungan, tidak terdapat beda nyata namun jumlah biji perbaris paling terbanyak pada kontrol. Demikian pula pengaturan jarak tanam doble row cendrung meningkat pada $(11,88)$ pengamatan dibanding single row.

Tabel 8. Jumlah Biji Per Baris

\begin{tabular}{|c|c|c|c|}
\hline \multirow{2}{*}{ Model Tumpang Sari } & \multicolumn{2}{|c|}{ Pengaturan Jarak Tanam } & \multirow{2}{*}{ Rerata } \\
\hline & Single Row & Doble Row & \\
\hline Kontrol & 10,92 & 15,50 & $12,48 \mathrm{a}$ \\
\hline Standar nasional & 10,89 & 12,59 & $11,74 \mathrm{a}$ \\
\hline Salome & 7,20 & 10,89 & $9,04 \mathrm{a}$ \\
\hline Gabungan SN-S & 10,92 & 8,53 & $9,73 \mathrm{a}$ \\
\hline Rerata & $9,62 \mathrm{a}$ & $11,88 \mathrm{a}$ & $(-)$ \\
\hline
\end{tabular}

Keterangan : Angka pada baris dan kolom yang diikuti dengan huruf yang sama menunjukkan tidak berbeda pada tingkat nyata $(\alpha) 5 \%$ menurut uji DMRT; (-): Tidak terjadi interaksi antar faktor.

\subsection{Jumlah Biji Per Tongkol}

Hasil sidik ragam (Anova) menunjukkan tidak terjadi interaksi antara model tumpangsari dan pengaturan jarak tanam terhadap pengamatan jumlah biji pertongkol. Dimana tanpa ditumpangsarikan memiliki jumlah biji pertongkol tertinggi $(11,66)$ dibanding standar nasional, salome dan gabungan, tidak terdapat beda nyata namun jumlah biji pertongkolpaling terbanyak pada kontrol. Demikian pula pengaturan jarak tanam doble row cendrung meningkat $(10,52)$ pada pengamatan dibanding single row.

Tabel 9. Jumlah Biji Per Tongkol

\begin{tabular}{|c|c|c|c|}
\hline \multirow{2}{*}{ Model Tumpang Sari } & \multicolumn{2}{|c|}{ Pengaturan Jarak Tanam } & \multirow{2}{*}{ Rerata } \\
\hline & Single Row & Doble Row & \\
\hline Kontrol & 11,22 & 12,11 & $11,66 \mathrm{a}$ \\
\hline Standar nasional & 10,44 & 10,89 & $10,66 \mathrm{ab}$ \\
\hline Salome & 9,28 & 10,61 & $9,94 \mathrm{ab}$ \\
\hline Gabungan SN-S & 9,78 & 8,50 & $9,14 \mathrm{~b}$ \\
\hline Rerata & $10,18 \mathrm{a}$ & $10,52 \mathrm{a}$ & $(-)$ \\
\hline
\end{tabular}

Keterangan : Angka pada baris dan kolom yang diikuti dengan huruf yang sama menunjukkan tidak berbeda pada tingkat nyata $(\alpha) 5 \%$ menurut uji DMRT; (-): Tidak terjadi interaksi antar faktor.

\subsection{Berat Kering Biji Per Tongkol}

Hasil sidik ragam (Anova) menunjukkan tidak terjadi interaksi antara model tumpangsari dan pengaturan jarak tanam terhadap pengamatan berat kering biji pertongkol. Dimana tanpa ditumpangsarikan memiliki berat kering biji pertongkol tertinggi $(51,50)$ dibanding standar nasional, salome dan gabungan, tidak terdapat beda nyata namun berat biji pertongkol paling terbanyak pada kontrol. Demikian pula pengaturan jarak tanam doble row cendrung meningkat $(45,41)$ pada pengamatan dibanding single row.

Tabel 10. Berat Biji Per Tongkol (g)

\begin{tabular}{lllc}
\hline \multirow{2}{*}{ Model Tumpang Sari } & \multicolumn{2}{c}{ Pengaturan Jarak Tanam } & \multirow{2}{*}{ Rerata } \\
\cline { 2 - 3 } & Single Row & Doble Row & \\
\hline Kontrol & 36,88 & 66,12 & $51,50 \mathrm{a}$ \\
Standar nasional & 46,42 & 48,13 & $47,28 \mathrm{a}$ \\
Salome & 20,72 & 42,94 & $31,86 \mathrm{a}$ \\
Gabungan SN-S & 40,06 & 24,45 & $32,26 \mathrm{a}$ \\
\hline Rerata & $36,03 \mathrm{a}$ & $45,41 \mathrm{a}$ & $(-)$ \\
\hline
\end{tabular}

Keterangan : Angka pada baris dan kolom yang diikuti dengan huruf yang sama menunjukkan tidak berbeda pada tingkat nyata $(\alpha) 5 \%$ menurut uji DMRT; (-): Tidak terjadi interaksi antar faktor.

\subsection{Berat Kering Biji Per Petak}

Hasil sidik ragam (Anova) menunjukkan terjadi interaksi antara model tumpangsari dan pengaturan jarak tanam terhadap pengamatan berat kering biji perpetak. Dimana tanpa model tumpangsari dengan pengaturan jarak tanam doble row memiliki berat biji perpetak tertinggi $(269,31)$ dibanding perlakuan lainnya.

Tabel 11. Berat Kering Biji Per Petak (g)

\begin{tabular}{llll}
\hline \multirow{2}{*}{ Model Tumpang Sari } & \multicolumn{2}{c}{ Pengaturan Jarak Tanam } & \multirow{2}{*}{ Rerata } \\
\cline { 2 - 3 } & Single Row & Doble Row & \\
\hline Kontrol & $132,57 \mathrm{bc}$ & $269,31 \mathrm{a}$ & 200,94 \\
Standar nasional & $150,75 \mathrm{bc}$ & $160,91 \mathrm{bc}$ & 167,46 \\
Salome & $127,35 \mathrm{bc}$ & $209,57 \mathrm{ab}$ & 155,83 \\
Gabungan SN-S & $159,31 \mathrm{bc}$ & $91,62 \mathrm{c}$ & 125,47 \\
\hline Rerata & 142,50 & 182,85 & $(+)$
\end{tabular}

Keterangan : Angka pada baris dan kolom yang diikuti dengan huruf yang sama menunjukkan tidak berbeda pada tingkat nyata $(\alpha) 5 \%$ menurut uji DMRT; (+): Terjadi interaksi antar faktor.

\subsection{Berat Kering Biji Per Hektar}

Hasil sidik ragam (Anova) menunjukkan terjadi interaksi antara model tumpangsari dan pengaturan jarak tanam terhadap pengamatan berat kering biji perhektar. Dimana tanpa model tumpangsari dan pengaturan jarak tanam doble row memiliki berat kering biji perhektar tertinggi $(0,89)$ dibanding perlakuan lainnya.

\section{Tabel 12. Berat Kering Biji Per Hektar (t/ha)}

\begin{tabular}{lllc}
\hline \multirow{2}{*}{ Model Tumpang Sari } & \multicolumn{2}{c}{ Pengaturan Jarak Tanam } & \multirow{2}{*}{ Rerata } \\
\cline { 2 - 3 } & Single Row & Doble Row & \\
\hline Kontrol & $0,44 \mathrm{bc}$ & $0,89 \mathrm{a}$ & 0,66 \\
Standar nasional & $0,50 \mathrm{bc}$ & $0,54 \mathrm{bc}$ & 0,52 \\
Salome & $0,42 \mathrm{bc}$ & $0,69 \mathrm{ab}$ & 0,56 \\
Gabungan SN-S & $0,53 \mathrm{bc}$ & $0,30 \mathrm{c}$ & 0,41 \\
\hline Rerata & $0,47 \mathrm{a}$ & $0,60 \mathrm{a}$ & $(+)$
\end{tabular}

Keterangan : Angka pada baris dan kolom yang diikuti dengan huruf yang sama menunjukkan tidak berbeda pada tingkat nyata $(\alpha) 5 \%$ menurut uji DMRT; (+): Terjadi interaksi antar faktor.

\subsection{Berat $100 \mathrm{Biji}$}

Hasil sidik ragam (Anova) menunjukkan tidak terjadi interaksi antara model tumpangsari dan pengaturan jarak tanam terhadap pengamatan berat 100 biji. Dimana model tumpangsari sistem standar nasional memiliki berat 100 biji tertinggi $(51,50)$ dibanding standar nasional, salome dan gabungan, tidak terdapat beda nyata namun berat 100 biji paling terbanyak pada standar nasional S1. Demikian pula pengaturan jarak tanam doble row cendrung meningkat $(24,13)$ pada pengamatan dibanding single row.

\section{Tabel 13. Berat 100 Biji (g)}

\begin{tabular}{llll}
\hline \multirow{2}{*}{ Model Tumpang Sari } & \multicolumn{2}{c}{ Pengaturan Jarak Tanam } & \multirow{2}{*}{ Rerata } \\
\cline { 2 - 3 } & Single Row & Doble Row & \\
\hline Kontrol & 19,38 & 25,56 & $22,47 \mathrm{a}$ \\
Standar nasional & 23,32 & 25,56 & $24,49 \mathrm{a}$ \\
Salome & 19,73 & 24,84 & $22,29 \mathrm{a}$ \\
Gabungan SN-S & 20,03 & 20,45 & $20,24 \mathrm{a}$ \\
\hline Rerata & $20,61 \mathrm{a}$ & $24,13 \mathrm{a}$ & $(-)$ \\
\hline
\end{tabular}

Keterangan : Angka pada baris dan kolom yang diikuti dengan huruf yang sama menunjukkan tidak berbeda pada tingkat nyata $(\alpha) 5 \%$ menurut uji DMRT; (-): Tidak terjadi interaksi antar faktor.

\subsection{Berat Kering Berangkasan}

Hasil sidik ragam (Anova) menunjukkan tidak terjadi interaksi antara model tumpangsari dan pengaturan jarak tanam terhadap pengamatan berat kering berangkasan. Dimana tanpa ditumpangsarikan memiliki berat kering berangkasan tertinggi $(2,20)$ dibanding standar nasional, salome dan gabungan, tidak terdapat beda nyata namun berat kering berangkasan paling terbanyak pada kontrol. Demikian pula pengaturan jarak tanam single row cendrung meningkat $(1,74)$ pada pengamatan dibanding doble row.

$\underline{\text { Tabel 14. Berat Kering Berangkasan (t/ha) }}$

\begin{tabular}{llll}
\hline \multirow{2}{*}{ Model Tumpang Sari } & \multicolumn{2}{c}{ Pengaturan Jarak Tanam } & \multirow{2}{*}{ Rerata } \\
\cline { 2 - 3 } & Single Row & Doble Row & \\
\hline Kontrol & 2,15 & 2,26 & $2,20 \mathrm{a}$ \\
Standar nasional & 1,66 & 1,70 & $1,68 \mathrm{a}$ \\
Salome & 2,28 & 0,96 & $1,62 \mathrm{a}$ \\
Gabungan SN-S & 1,06 & 0,73 & $0,90 \mathrm{a}$ \\
\hline Rerata & $1,79 \mathrm{a}$ & $1,41 \mathrm{a}$ & $(-)$ \\
\hline
\end{tabular}

Keterangan : Angka pada baris dan kolom yang diikuti dengan huruf yang sama menunjukkan tidak berbeda pada tingkat nyata $(\alpha) 5 \%$ menurut uji DMRT; (-): Tidak terjadi interaksi antar faktor. 


\subsection{Indeks Panen}

Hasil sidik ragam (Anova) menunjukkan tidak terjadi interaksi antara model tumpangsari dan pengaturan jarak tanam terhadap pengamatan indeks panen. Dimana model tumpangsari salome (S2) memiliki indeks panen tertinggi $(19,48)$ dibanding standar nasional, gabungan,dan kontrol tidak terdapat beda nyata namun indeks panen paling tinggi pada salome. Demikian pula pengaturan jarak tanam doble row cendrung meningkat pada pengamatan $(13,96)$ dibanding single row

\section{Tabel 15. Indeks Panen (\%)}

\begin{tabular}{lllc}
\hline \multirow{2}{*}{ Model Tumpang Sari } & \multicolumn{2}{c}{ Pengaturan Jarak Tanam } & \multirow{2}{*}{ Rerata } \\
\cline { 2 - 3 } & Single Row & Doble Row & \\
\hline Kontrol & 5,82 & 10,67 & $8,24 \mathrm{~b}$ \\
Standar nasional & 11,37 & 8,82 & $10,09 \mathrm{ab}$ \\
Salome & 16,56 & 22,40 & $19,48 \mathrm{a}$ \\
Gabungan SN-S & 13,23 & 13,94 & $13,59 \mathrm{ab}$ \\
\hline Rerata & $11,74 \mathrm{a}$ & $13,96 \mathrm{a}$ & $(-)$ \\
\hline
\end{tabular}

Keterangan : Angka pada baris dan kolom yang diikuti dengan huruf yang sama menunjukkan tidak berbeda pada tingkat nyata $(\alpha) 5 \%$ menurut uj DMRT; (-): Tidak terjadi interaksi antar faktor.

\subsection{Kejadian Penyakit Bulai}

Hasil sidik ragam (Anova) menunjukkan tidak terjadi interaksi antara model tumpangsari dan pengaturan jarak tanam terhadap pengamatan penyakit bulai. Dimana standar nasional memiliki penyakit bulai terbanyak $(8,33)$ dibanding salome, gabungan, dan kontrol tidak terdapat beda nyata namun kejadian penyakit bulai paling terbanyak pada Standar nasional. Demikian pula pengaturan jarak tanam single row cendrung meningkat pada pengamatan dibanding doble row.

Tabel 16. Kejadian Penyakit Bulai

\begin{tabular}{lllc}
\hline \multirow{2}{*}{ Model Tumpang Sari } & \multicolumn{2}{c}{ Pengaturan Jarak Tanam } & \multirow{2}{*}{ Rerata } \\
\cline { 2 - 3 } & Single Row & Doble Row & \\
\hline Kontrol & 8,33 & 7,00 & $7,66 \mathrm{a}$ \\
Standar nasional & 8,66 & 8,00 & $8,33 \mathrm{a}$ \\
Salome & 9,00 & 5,33 & $7,16 \mathrm{a}$ \\
Gabungan SN-S & 6,00 & 8,33 & $7,17 \mathrm{a}$ \\
\hline Rerata & $8,00 \mathrm{a}$ & $7,17 \mathrm{a}$ & $(-)$ \\
\hline
\end{tabular}

Keterangan : Angka pada baris dan kolom yang diikuti dengan huruf yang sama menunjukkan tidak berbeda pada tingkat nyata $(\alpha) 5 \%$ menurut uji DMRT; (-): Tidak terjadi interaksi antar faktor.

\subsection{Land Equivalend Ratio}

Hasil sidik ragam (Anova) menunjukkan tidak terjadi interaksi antara mode tumpangsari dan pengaturan jarak tanam terhadap pengamatan LER. Model tumpangsari standar nasional dan salome memiliki nilai rata-rata yang sama namun tidak menunjukan beda nyata sedangkan pada pengaturan model jarak tanam single row menunjukan beda nyata dibanding doble row (Tabel 17.). Model tumpangsari yang diterapkan menghasilkan LER $<1$ yang berarti merugikan pada semua perlakuan,sedangkan pada pengaturan jarak tanaman menunjukkan sistem single row $>1$ yang berarti menguntungkan yang berbeda nyata dengan pengaturan jarak tanam doble row.Hal ini berarti pada model single row lebih cocok diterapkan pada tumpangsari jagung dan kacang nasi.Pola tumpangsari antara tanaman jagung dan kacang nasi dalam penelitian in menunjukkan nilai LER jagung $>1$ pada pengaturan jarak tanam single row sangat cocok dan sangat layak untuk diterapkan. Hal ini senada dengan pernyataan Ceunfin et al., (2017), bahwa nilai LER dan ATER >1 menggambarkan sistem tanaman monokultur memerlukan lahan yang lebih luas dibandingkan dengan pola tumpangsari.

Tabel 17. Land Equivaland Ratio Jagung

\begin{tabular}{llll}
\hline \multirow{2}{*}{ Model Tumpang Sari } & \multicolumn{2}{c}{ Pengaturan Jarak Tanam } & \multirow{2}{*}{ Rerata } \\
\cline { 2 - 3 } & Single Row & Doble Row & \\
\hline Standar nasional & 1,15 & 0,63 & $0,89 \mathrm{a}$ \\
Salome & 0,95 & 0,82 & $0,89 \mathrm{a}$ \\
Gabungan SN-S & 1,20 & 0,34 & $0,77 \mathrm{a}$ \\
\hline Rerata & $1,10 \mathrm{a}$ & $0,60 \mathrm{~b}$ & $(-)$ \\
\hline
\end{tabular}

Keterangan : Angka pada baris dan kolom yang diikuti dengan huruf yang sama menunjukkan tidak berbeda pada tingkat nyata $(\alpha) 5 \%$ menurut uji DMRT; (-): Tidak terjadi interaksi antar faktor.

\subsection{Pembahasan}

Sistem model tumpangsari dan pengaturan jarak tanam, terjadi peningkatan produktivitas lahan. Penyebab peningkatan produktivitas lahan karena tepatnya penentuan sistem pertanaman yang digunakan. Menurut Mugnisjah \& Setiawan (1990), peningkatan produktivitas lahan disebabkan oleh pemilihan kombinasi tanaman dan sistem pertanaman yang tepat. Di samping itu juga adanya hubungan atau simbiosis mutualisme antar tanaman jagung dengan kacang nasi yang ditanam secara tumpangsari Simbiosis tersebut terkait dengan kebutuhan nitrogen bagi tanaman jagung yang terpenuhi dari kacang nasi/fuemtas'ana melalui kemampuannya memfiksasi nitrogen dari udara, sebaliknya kacang nasi yang toleran terhadap naungan dapat hidup di bawah tegakan jagung. Hosang et al. (2004) menyatakan kombinasi tanaman serealia dengan tanaman legum adalah kombinasi yang terbaik sebab kompetisi antar bagian tanaman dalam hal memperoleh sinar matahari dan unsur hara relatif sangat kecil.

Kondisi lingkungan tumbuh tanaman seperti suhu tanah menurun pada pengamatan 28 dan 42 HST, kadar lengas tanah meningkat pada kontrol, berdampak padasetiap parameter pertumbuhan tanaman jagung lokal,yang tanpa di tumpangsarikan dengan kacang nasi, pertumbuhan dan hasilnya jauh lebih baik dibandingkan dengan model tumpang sari standar nasional, salome dan gabungan dengan Berat kering biji per petak $(269,31)$ dan berat kering biji per hektar $(0,66)$ yang terjadi interaksi dan beda nyata dibanding perlakuan lainnya. Kondisi seperti ini diduga karena terjadi kompetisi pada tanaman jagung dan tanaman kacang nasi.

Kompetisi merupakan suatu bentuk interaksi antar tumbuhan yang saling memperebutkan sumberdaya alam seperti air, hara, cahaya dan ruang tumbuh yang ketersediaannya terbatas pada lahan dan pada waktu yang sama dapat menimbulkan dampak negatif terhadap pertumbuhan dan hasil salah satu jenis tumbuhan atau lebih (Crowder, 1986), dimana terbukti dalam penelitian ini bahwa hasil terbaik terdapat pada tanaman yang tidak ditumpangsarikan (kontrol).

Faktor pembatas lainnya dalam penelitian ini adalah jenis tanah muda (inseptisol) yang mencirikan ketersedian haranya terbatas serta merupakan tanah marginal, serangan penyakit bulai yang menyebabkan proses fotosintesis menurun sehingga hasil asimilat yang tersimpan dalam biji menjadi lebih rendah. Namun dengan tumpangsari dapat meningkatkan produktifitas lahan maupun tanaman. Mugnisjah \& Setiawan (1990) menyatakan peningkatan produktivitas lahan disebabkan oleh pemilihan kombinasi tanaman dan sistem pertanaman yang tepat serta adanya hubungan atau simbiosis mutualisme antar tanaman yang ditanam secara tumpangsari. Kombinasi tanaman serealia dengan tanaman legum adalah kombinasi yang terbaik (Ceunfin, et al., 2017), namun perlu memperhatikan tajuk tanaman legum terutama jenis Vigna angularis L.

\section{Simpulan}

Model tumpang sari dan pengaturan jarak tanam memberikan pengaruh interaksi terhadap berat kering biji per petak, berat kering biji per hektar. Kombinasi perlakuan model tumpangsari Salome dengan pengaturan jarak tanam doble row memberikan hasil berat kering biji per petak dan per hektar paling tinggi yaitu sebesar 269,31 $\mathrm{g}$ dan $0,89 \mathrm{t} / \mathrm{ha}$.

Pustaka

Agustina. 2008. Dasar Nutrisi Tanaman. Cetakan kedua. Jakarta: Bhineka Cipta. BPS NTT. 2014. Nusa Tenggara Timur Dalam Angka. Kupang: BPS NTT. BPS TTU. 2012. Timor Tengah Utara Dalam Angka. Kefamenanu: BPS TTU.

Beets, W.C. 1982. Multiple Cropping and Tropical Farming System. Chicago: Gower Publ Co.

Ceunfin, S., Prajitno, D., Suryanto, P. \& Putra, E.T.S. 2017. Penilaian Kompetisi dan Keuntungan Hasil Tumpangsari Jagung Kedelai di Bawah Tegakan Kayu Putih. Savana Cendana, 2(01): 1-3.

Crowder, L.V. 1986. Genetika Tumbuhan, Edisi indonesia. Yogyakarta: Gadjah Madah University Press.

Gomez, K.A. \& Gomez, A.A. 1984. Statistical Procedures for Agricultural Research. New York: John Wiley \& Sons.

Harjadi, S.S. 2002. Pengantar Agronomi. Jakarta: PT. Gramedia.

Hosang, E.Y., S. Barhiman, I.N.P. Soetedjo. 2004. Pola pertanaman ladang rendah resiko di daerah tangkapan air Bendungan Tilong, Kabupaten Kupang, Nusa Tenggara Timur. http://www.filesking.net (10 Januari 2012). Irfan, 1999. Bertanam Kacang Sayuran. Jakarta: Penebar Swadaya.

Mayadewi, N. N. A. 2007. Pengaruh Jenis Pupuk Kandang dan Jarak Tanam terhadap Pertumbuhan Gulma dan Hasil Jagung Manis. Jurnal Bidang Ilmu Pertanian, 26(4): 153-159.

Mugnisjah, W.G. dan Setiawan, A,, 1990. Pengantar Produksi Benih. Jakarta: PT. Raja Grafindo Persada.

Suarni. 2001. Sosial Ekonomi Nasional (Susenas).

Setiawan E. 2009. Kearifan Lokal Pola Tanam Tumpangsari di Jawa Timur. Agrovigor, 2(02): 79-88.

Setyamidjaja, D, 2000. Pola tanam dan jarak tanam. Yogyakarta: Kanisius.

Warsawa 2009. Introduksi Teknologi Tumpangsari Jagung dan Kacang Tanah. Tabloid Sinar Tani. 